\title{
READERS
Insight
}

Journal of Management Info (JMI)

ISSN:2313-3376

www.readersinsight.net/jmi

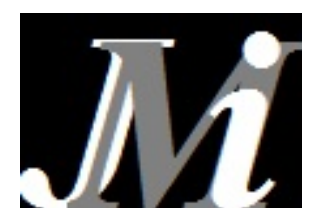

\section{Analysis of FDI and financial improvements for the economic growth}

\author{
Nadia Bukhari ${ }^{1 *}$, Atiq ul Rehman Malik² \\ ${ }^{1}$ COMSATS Institute of Information Technology, Department of Management Sciences, 43600, Attock, Pakistan \\ * Corresponding author: nadiabukhari29@gmail.com
}

\begin{abstract}
This study is conducted in order to check the long run as well as short run impact of FDI and Financial Development on the economic growth. The study is conducted in the scenario of Pakistan and the time series data is taken for the year 1972-2013. ARDL methodology is used to determine whether FDI has long term impact on Economic growth or not. Moreover Granger Causality is used to check a uni-directional relationship and the results support that FDI has an impact over economic growth. Furthermore it is depicted from ARDL that there is a positive relationship between FDI and Economic Growth.
\end{abstract}

\section{ARTICLE INFORMATION}

\author{
Received: 25 January 2017 \\ Revised: $\quad 25$ February 2017 \\ Accepted: 25 March 2017
}

DOI:

http://dx.doi.org//10.31580/jmi.v13i1.68

\section{Introduction}

Since 1947, Pakistan is struggling for the economic development though it had to face challenges. In Pakistan, in 2014 Gross Domestic Product (GDP) increased 5\% from the past year. Economic growth in Pakistan is $4.93 \%$ on average from 1952 to 2014 , it reached to its peak to $10.22 \%$ in 1954 and touched its bottom to $-1.80 \%$ in 1952 . Pakistan Bureau of Statistics reports economic growth (GDP) in Pakistan.

Goldsmith (1969) and Mckinnon (1973) studied the relationship between financial development and economic growth for the first time. This relationship has been a crucial issue of debate in the developing countries. The theoretical discussion over connecting financial development to the economic growth is that the well developed economic climate execute many crucial features to boost the performance regarding intermediation by means of decreasing the transaction of information as well as monitoring expenses. Today's economic climate encourages and welcome investment by figuring out as well as financing different business opportunities, keeping an eye on manager's performance. It permits hedging, diversification, trading of risk. It further encourages the trade of goods as well as services. All this result into the more effective and wise allocation of the assets $\mathrm{n}$ resources whether they $\mathrm{r}$ physical resource or human resource(Creane et al., 2004). Well (Saibu, et al. 2011) studied detailed impact of financial development and FDI on economic growth in Nigeria and concluded his analysis by declaring positive relationship among variables. Moreover (Omranyz and Bolbolz, 2003) also studied the detailed relationship of economic growth, financial development and foreign Direct investment in the scenario of Arab countries and concluded that the relationship is positive.

This very paper is also depicting the work on all these three variable Economic Growth, Financial Development and Foreign Direct Investment. But what makes it different is that all these three variables are going to be studied together in the scenario of Pakistan for the period of 1972-2013.
This paper further includes the literature review in which the work of peers is discussed. Then variable construct is made in which all variable are discussed in details and the work on these variables with reference of the work done by peers. Moreover estimation strategy is made in which models and testing procedures are mentioned. Then the empirical results are obtained by applying model. The results are mention and at the last step the conclusion is drawn with some suggestions.

\section{Literature review}

The part of FDI and monetary segment advancement on financial development has been generally examined in literature. De Mello (1997) in his research is quite satisfied that FDI enhance the long run monetary development through innovative pogress, capital collection and human capital growth. The part of money related segment improvement on financial development was initially considered. Afterwards analyzed by Patrick (1966) asserted that economic part impels fiscal developments by means of the accompanying channels: reallocation of assets from conventional to development affecting divisions and the advancement of business in development instigating parts. Later studies have utilized the endogenous development hypothesis methodology to study the part of money related area improvement of financial development. Greenwood and Jovanovic (1990) demonstrated that monetary establishments assume an imperative part in gathering and breaking down data of firms and markets. Likewise contended that budgetary advancement expands the profit for development by giving three administrations. These administrations incorporate the accompanying: viable assessment of speculation undertakings through the securing of data; capacity to pool and assemble family funds for creative attempts'; and, capacity to impart and enhance dangers to upgrade advancement of halfway merchandise. The most current studies have employed the endogenous enhancement program in order to capture the related result associated with FDI as well as funds associated department progression upon financial improvement. (Hermes and Lensink, 
2003), concluded in their research that the cost associated with progression was understood to be the capacity assiciated with FDI in wich the cost drops because FDI influx builds. The study demonstrated that budgetary part improvement builds the rate of advancement and innovative overflows through FDI. Employing the OLS technique, the research exhibited that FDI will simply posses an optimistic impact on financial enhancement when the household financial department is developed half way decent. Relative outcome was obtained from (Alfaro et al., 2004) utilizing managing an account division markers and securities exchange pointers. Utilizing board information investigation, Omran and Bolbol (2003) applied pooled OLS upon 17 Middle East countries and discovered that the impact of FDI on financial enhancement depends upon advancement of monetary part. Then, utilizing the distinction 1GMM estimator, (Bailliu, 2000) in his research discovered that funds avnues can just improve monetary development in nations with sufficiently-created money related division. The related impact employing Johansen multivariate co-mix procedure and Granger Causality check for three advanced countries (Japan, US, UK) as well as six East Asian countries. The research deduced that over the extended haul, monetary area advancement is pivotal for FDI to have positive consequences for financial development in seven omong nine countries determined, although short run causality checks revealed that money related division improvement is imperative in six among nine counties determined. In afterward research, linked the limits test as well as unhindered slip revision model (UECM) method in Malaysia and found relative summary for both the long run as well as the short run. This research revealed the short run mobility for FDI, monetary region betterment and the relative impact higher than their relating long run versatility. Then again, Alfaro et al. (2006) has given a hypothetical model in which monetary part advancement impacts the degree to which FDI improves larger financial enhancement in to host nations through retrogressive linkages. Particularly, by facilitating credit requirements through lower giving and obtaining rates, money related area advancement has the capacity encourage linkages among rural firms and household firms. The modification analysis depicts that countriess with much created monetary part have a tendency to have higher profits of FDI for financial development. There are additionally various studies that have demonstrated that the corresponding speculation is not backed. Case in point, Durham (2004) exactly demonstrated that the corresponding impact in the middle of FDI and budgetary part advancement was not measurably huge in affecting financial development. This study utilized stock exchange market and represented synchronization inclination. Actually, (Carkovic and Levine, 2002) connected framework GMM estimator and determined that economic division progression was not essential in influencing FDI to help financial development and economic improvement. In synopsis, the research surveyed have insofar been vague on perhaps the relatinging influence of FDI on money related segment advancement is essential in encouraging financial development. Subsequently, this research will review this relationship in the case of Asia as well as Oceania nations utilizing conventional board information routines.

\section{Variable construct}

Variables which have been used by different researchers to see influence of FDI and Financial Enhancement on GDP (Economic growth) are going to be observed in this research paper as well to see the influence of FDI as well as Financial enhancement on Economic boost. Foreign Direct Investment is an independent variable which brings changes to dependent variable which is GDP. The empirical study demonstrates that financial sector enhancement boosts the share of FDI on economic development. The same FDI has been used as a dependent variable by De Mello (1997 and Patrick (1966). They have examined the effects of changes in FDI as independent variable on Economic growth and found that the function of FDI as well as monetary segment development on economic development is most significant for least developed financial system. The research carried out by them envisages D8 countries, Malaysia and17ARAB countries.
I will be using the same variable in my research. GDP has been selected as dependent variable which gets affected by increase or decrease in foreign direct investment. GDP depends on the local industries attracting foreign investment, monetar segment development influences the degree to which FDI encourages higher monetary progress in host nations via backward linkages. The innovation sector demands cash flow by foreign and local government as investors. The same variable has been used by (Lensink, 2003), (Omran and Bolbol, 2003), to examine the affect of FDI increase or decrease on economic development globally. I will be using the same variable in this research which is the influence of FDI and finical enhancement on economic development. Financial enhancement involves the finical intuitional bodies' cash growth or decrease. In order to measure effect of foreign direct investment over economic development and finical development, Following persons have used panel data analysis of 17 Arab countries (Bailliu,2000). (Omran and Bolbol, 2003), Alfaro et al. (2006) and found the influence of foreign direct investment over finical development. Rose Levine from university of Verginia has proved in his research article that there is very strong relation among per capita real GDP as well as of financial improvement. One of the most important measures of financial enhancement is BANK which calculates the extant to which the state bank and commercial banks are allocating credit.

\section{Estimation strategy}

Autoregressive Distributed Lag (ARDL) approach is a new approach which was introduced by (Pesaran and Pesaran, 1997), (Pesaran and Smith, 1998), (Pesaran and Shin, 1999), and (Pesaran et al. 2001). This approach is based on the general-to-specific modeling method. In this paper, in order to find out the long run effects of financial development and stock traded on economic growth, ARDL technique is applied.

The ARDL approach has an edge over several other approaches of cointegration.

i) It is generally used irrespective of whether the fundamental variables tend to be $\mathrm{I}(0)$, $\mathrm{I}(1)$ or perhaps a combination of both (Pesaran and Pesaran 1997).

ii) This particular approach contains sufficient number of lags in order to cover the whole data or the information generating procedure, generally to modeling frameworks.

iii) The error correction model (ECM) is the outcome of a simple transformation which combines short run modifications and long run stability without sacrificing long run data and facts.

iv) The minimum sample properties from ARDL technique is considered more advanced than those of Johensen as well as Juselius cointegration approach (Pesaran and Shin, 1999).

v) Endogeneity is considered as less of an issue for the ARDL approach as it is without any residual correlation. (Pesaran and Shin, 1999) depicted the side wise estimation of long-run as well as shortrun components and suitable lags or gaps in ARDL framework eliminate the problem which is related to serial correlation and endogeneity problems.

vi) The ARDL approach can certainly differentiate among dependent as well as independent variables.

The model will be written as:

$$
\Delta G D P_{i}=\beta_{0}+\sum_{i=1}^{p} \phi_{i} \Delta G D P_{t-i}+\sum_{i=1}^{p} \phi_{i} \Delta F D I_{t-i}+\sum_{i=1}^{p} \phi_{i} \Delta F D_{t-i}+\lambda G D P+\lambda_{1} F D I_{t-1}+\lambda_{2} F D_{t-1}+U_{t}
$$

Here $\beta_{0}$ is representing the constant and $\mu_{t}$ is representing white noise. The terms having summation signs show the error correction dynamics, while $\lambda$ in the second part is depicting the long run relationship. In the ARDL, the very first step which is required to test this approach is to apply F-tests on the existing long run links between the variables.

The null hypothesis is $\mathrm{H} 0: \lambda 1=\lambda 2=0$.

This shows the presence of a long run relationship.

The alternative hypothesis is $\mathrm{H} 1: \lambda 1 \neq 0, \lambda 2 \neq 0$. 
The F-statistics is applied and then compared with the two sets of critical values by (Pesaran et al. 2001). One set contains $I(0)$ series where the other one contains I(1)series. In case if F-statistics lies in the upper critical value, the null hypothesis would be rejected depicting zero cointegration. Regardless of whether the variables are $\mathrm{I}(0)$ or may be I(1). But if it lies below the lower value then null hypothesis will no more be rejected. But the test is said to be inconclusive if the value lies in the critical value band (Pesaran and Pesaran, 1997). To obtain most suitable lag length for each and every variable, ARDL approach calculates $(\mathrm{p}+1)^{\mathrm{k}}$ number of regressions. A ' $\mathrm{P}$ ' show the maximum lags and ' $\mathrm{k}$ ' shows the number of variables. Schwartz-Bayesian Criteria (SBC) and the Akaike Information Criteria (AIC) are the criteria for selecting the model. SBC measures minimum possible lag length where as AIC measures the maximum relevant lag length.

Furthermore, long run can be estimated through SBC and AIC by using ARDL approach. Error correction representation is required when estimation long run.

$$
\Delta G D P_{i}=\beta_{0}+\sum_{i=1}^{p} \phi_{i} \Delta G D P_{t-i}+\sum_{i=1}^{p} \phi_{i} \Delta F D I_{t-i}+\sum_{i=1}^{p} \phi_{i} \Delta F D_{t-i}+\alpha E C M_{t-1}+U_{t}
$$

Error correction term ECM demonstrates the adjustment of long run stability from a short run shock. Diagnostic as well as stability tests are performed in order to check goodness of fit and check the overall explanatory power of model. This method is famous as cumulative sum (CUSUM) as well as cumulative sum of squares (CUSUMSQ). If the plots of the CUSUM and CUSUMSQ statistics stay within the critical bonds of a $5 \%$ level of significance, the null hypothesis of all coefficients in the given regression is stable and cannot be rejected. For the application of these estimation methods, World Development Indicators are used to gather time series data.

\section{Empirical results}

All the variables FDI, FD and GDP are non stationary at its level but eventually become stationary at its first difference.

Table 1: K Values and Stationary Level

\begin{tabular}{lllll}
\multicolumn{6}{l}{ Table 1: K Values and Stationary Level } \\
\hline Variables & Level & $\mathbf{K}$ & $\mathbf{1}^{\text {st }}$ difference & $\mathbf{K}$ \\
\hline FDI & -2.7889 & 1 & -2.4986 & 0 \\
FD & -2.902 & 1 & -0.2923 & 0 \\
GDP & -2.2591 & 0 & -1.007 & 1 \\
\hline
\end{tabular}

Source: The author's calculations

Table 2: Granger Causality Test

\begin{tabular}{lll}
\hline Hypothesis & F-statistics & Probability \\
\hline $\mathrm{H}_{\circ} ;$ FDI doesn't granger cause GDP & 3.4831 & 0.0912 \\
$\mathrm{H}_{\mathrm{A} ;}$ GDP doesn't granger cause FDI & 0.6231 & 0.9962 \\
\hline
\end{tabular}

Source: The author's calculations

It is still not revealed that whether FDI has influence over Economic growth or Economic growth has impact over FDI. For this purpose in order to check out uni-directional relationship among variables Granger Causality test is employed. The values of F-statistics as well as probability are obtained. The values are depicting that $\mathrm{H}_{0}$ is rejected supporting a uni-directional result that FDI influence on GDP.

Table 3: Long Run Results of ARDL

\begin{tabular}{lll}
\hline Regressors & Coffecient Value & T-values \\
\hline Constant & 0.2531 & 2.5283 \\
FDI & 0.3185 & 2.0350 \\
FD & 0.2376 & 3.8145 \\
& & \\
Diagnostic tests & & P-Values \\
Serial correlation & & 0.5629 \\
Functional Form & & 0.61900 \\
Normality & & 0.7607 \\
Hetroskedesticity & 0.1672 \\
\hline Dependent variable is GDP &
\end{tabular}

\section{Source: The author's calculations}

Equation (2) is estimated using ARDL methodology in order to get long run results. In order to get the values of parameters of variables Quinn criterion, SBC criterion, AIC criterion and $\mathrm{R}^{2}$ criterion is used. The results of both the models of short run as well as long run are almost same. In the long run the value of constant is 0.2531 which means if FD has no impact on GDP then even though GDP will be 0.2531 . The coefficient of FDI is 0.3185 which means $1 \%$ increase in FDI will lead to increase GDP by $31.85 \%$ where as the coefficient of FD is 0.2376 which means $1 \%$ increase in FD will lead to increase GDP by $23.76 \%$. Further diagnostic Test is performed in order to check serial correlation, functional form, normality and Hetroskedisticity. The results from these tests showed that there is no serial correlation and functional form, the data is normally distributed and there is no problem of hetroskedesticity.

Table 4: Short run results of ARDL

\begin{tabular}{lll}
\hline Regressors & Coffecients & T-Values \\
\hline Constant & 0.1816 & 0.1564 \\
$\Delta$ FDI & 0.2429 & 0.9884 \\
$\Delta$ FD & 0.1867 & 1.4107 \\
ECM & -0.0842 & -0.2011 \\
& & \\
Diagnostic Test & & P-Value \\
$R^{2}$ & & 0.8142 \\
D.W & & 1.8621 \\
\hline
\end{tabular}

Dependent variable is GDP

Source: The author's calculations

In short run results the coefficient of FDI in short run is 0.2429 so it means $1 \%$ increase in FDI will lead to increase GDP by $24.29 \%$. Similarly the coefficient of FD is 0.1867 which means that $1 \%$ increase in FD will lead to increase GDP by $18.67 \%$. Values of ECM show that there is a significant relationship among variables. $18 \%$ will be corrected in one year so $100 \%$ will take almost 5 years to be corrected. Further the results of $\mathrm{R}^{2}$ show that FDI reasonably determine GDP and the results from Durbin-Watson test show that there is no auto correlation exists between variable. (Omranyz and Bolbolz, 2003), (Creane et al., 2004) and (Saibu, et al. 2011) also studied the impact of economic growth on FDI and Financial Development and supports the same result as that of this paper.Study utilized CUSUM and CUSUMSQ techniques to check the stability if the model. Statistics indicate that CUSUM and CUSUMSQ are within critical bound shown in Fig. 1 and Fig. 2.

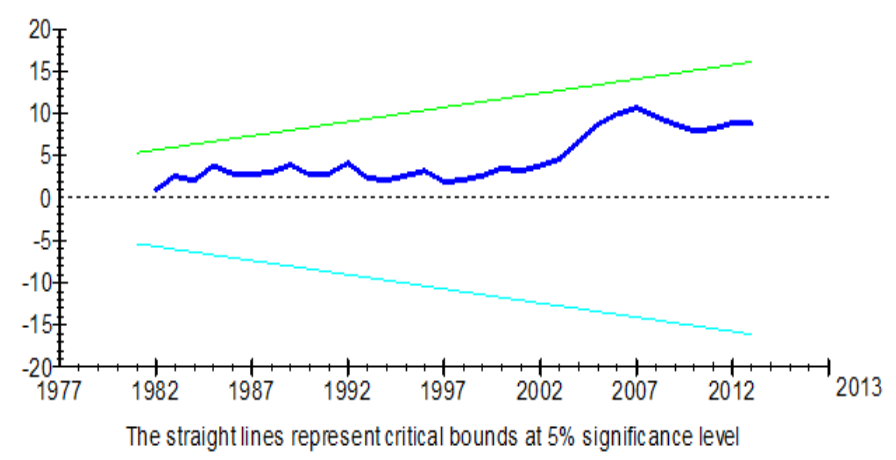

Fig. 1. Plot of Cumulative Sum of Recursive Residual 


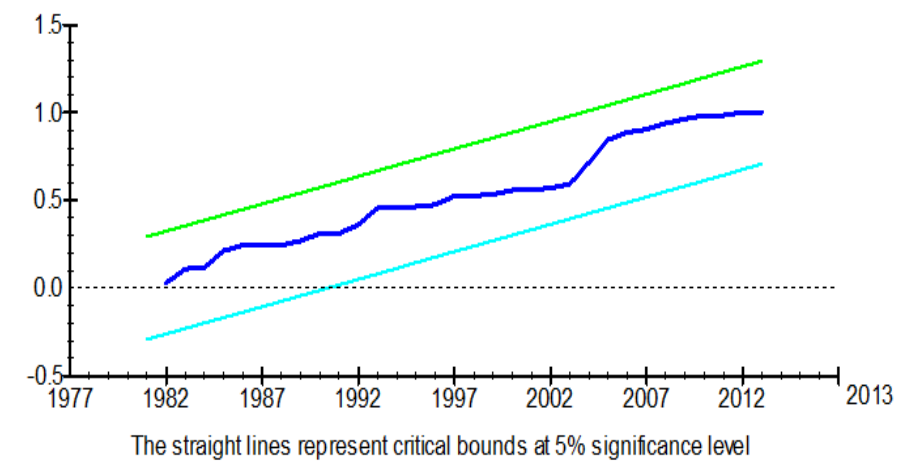

Fig. 2. Plot of Cumulative Sum of Squaes of Recursive Residual

\section{Conclusion}

The basic objective of this study is to analyze the impact of FDI and Financial Development on the Economic Growth in case of Pakistan for the period of 1972-2013. The technique used in this paper is ARDL in order to check the long run as well as short run relationship among variables. The empirical results support that there exist a long run relationship among variables. Granger causality test is employed and the results showed that there is a uni directional relationship among variables and FDI impacts on GDP. CUSUM and CUSUMSQ techniques which are applied on ECM show that coefficients of Model are sound. The empirical results depicted that there is a positive relationship among FDI and GDP.

The paper would be beneficial for analyzing the long run impact of FDI on GDP in case of Pakistan. It further supports that FDI positively influence the Economic growth. Moreover, there is a room for study for the new researchers. In this study while analyzing FD over all data is taken, but if the data is taken from a particular sector the results could be better.

\section{References}

Alfaro, L., Kalemli-Ozcan, S., \& Sayek, S. (2009). FDI, productivity and financial development. The World Economy, 32(1), 111-135.

Bailliu, J. N. (2000). Private capital flows, financial development, and economic growth in developing countries. Bank of Canada.

Creane, S., Goyal Rishi, A. Mushfiq Mobarak, and Randa Sab (2004) Financial Sector Development in the Middle East and North Africa.
International Monetary Fund, Washington, D.C. (IMF Working Paper 04/201.)

Carkovic M, Levine R (2002). Does Foreign Direct Investment Accelerate Economic Growth? in H. T. Moran, E. Graham and M.Blomstrom (eds.), Does FDI Promote Development? Washington, DC: Institute for International Economics.

de Mello Jr, L. R. (1997). Foreign direct investment in developing countries and growth: A selective survey. The Journal of Development Studies, 34(1), 1-34.

Durham, J. B. (2004). Absorptive capacity and the effects of foreign direct investment and equity foreign portfolio investment on economic growth.European economic review, 48(2), 285-306.

Goldsmith, R. W. (1969) Financial Structure and Development. New Haven, C.T.: Yale University Press.

GREENWOOD, J. and R. JOVANOVIC (1990), "Financial development, growth and the distribution of income" Journal of Political Economy, 98(5), October.

Hermes, N., \& Lensink, R. (2003). Foreign direct investment, financial development and economic growth. The Journal of Development Studies, 40(1), 142-163.

King, R. G., \& Levine, R. (1993). Finance, entrepreneurship and growth. Journal of monetary Economics, 32(3), 513-542.

King, R. G., and R. Levine (1993a) Finance, Entrepreneurship and Growth. Journal of Monetary Economics 32, 30-71.

Mckinnon, R. I. (1973) Money and Capital in Economic Development. Washington, D. C.: Brooking Institution.

Omran, M., \& Bolbol, A. (2003). Foreign direct investment, financial development, and economic growth: evidence from the Arab countries. Review of Middle East Economics and Finance, 1(3), 231-249.

Pesaran, M.H., Pesaran, B., 1997. Working With Microfit 4.0: Interactive Econo- metric Analysis. Oxford University Press, Oxford.

Pesaran, M.H., Shin, Y., 1999. An autoregressive distributed lag modelling approach to cointegration analysis. In: Strom, S. (Ed.), Econometrics and Economic Theory in 20th Century: The Ragnar Frisch Centennial Symposium. Cambridge University Press, Cambridge Chapter 11.

Pesaran, M.H., Smith, R.P., 1998. Structural analysis of cointegrating VARs. Journal of Economic Survey 12, 471-505.

Pesaran, M.H., Shin, Y., Smith, R.J., 2001. Bounds testing approaches to the analysis of level relationships. Journal of Applied Econometrics 16, 289 326.

Patrick, H. T. (1966). Financial development and economic growth in underdeveloped countries. Economic development and Cultural change, 174-189.

Saibu, M. O., Nwosa, I. P., \& Agbeluyi, A. M. (2011). Financial development, foreign direct investment and economic growth in Nigeria. Journal of Emerging Trends in Economics and Management Sciences, 2(2), 146-154. 